\section{Probing RNA Folding Pathways by RNA Fingerprinting}

Many RNA sequences form more than one stable secondary or tertiary structure under physiological conditions. As these conformations frequently exchange with one another in a period of minutes or seconds, solution-based methods are often inadequate to resolve differences in their structure and activity. This unit describes methods for separating RNA conformers by native polyacrylamide gel electrophoresis. The activity of each electrophoretic species is assayed while the RNA is still immobilized in the gel matrix. The protocols given here were initially developed to discriminate between active and inactive conformation of the self-splicing RNA from Tetrahymena thermophila (Emerick and Woodson, 1994), but can be applied to a wide variety of catalytic RNAs and RNA-protein complexes.

Native polyacrylamide gel electrophoresis is used to separate uniformly ${ }^{32} \mathrm{P}$-labeled RNA on the basis of shape or hydrodynamic radius (see Basic Protocol 1). Once optimal electrophoretic separation has been achieved, the catalytic activity of each conformer is determined in situ by soaking substrates into the gel matrix (see Basic Protocol 2). Alternatively, the RNA can be eluted from the gel and analyzed directly (see Alternate Protocol). The secondary structure of the RNA is probed by addition of base-modification reagents to the RNA in the gel (see Basic Protocol 3).

CAUTION: This procedure should be performed only by personnel trained in the use of radioactive materials and in NRC-licensed sites. Standard precautions to minimize exposure and prevent radioactive contamination of personnel and equipment should be followed at all times. ${ }^{32} \mathrm{P}$ is a high-energy $\beta$ emitter and requires shielding of personnel.

NOTE: Care must be taken to avoid introducing ribonucleases into the samples. All solutions should be prepared with deionized water $(18 \mathrm{M} \Omega)$ that is free of pyrogens and organic contaminants. Although less desirable, water treated with diethylpyrocarbonate (DEPC; APPENDIX 2A) may be used if a supply of RNase-free water is not available. DEPC must be allowed to decompose completely before use (e.g., by autoclaving), as it reacts with nucleic acids and Tris base. Solutions should be sterilized by filtration $(0.2 \mu \mathrm{m})$ or autoclaved. Gloves must be worn while handling samples and preparing solutions, and pipet tips and sample tubes must be free of nucleases. This can usually be achieved by purchasing good quality machine-packaged disposable plasticware, avoiding contact with bare skin, and storing disposables in clean, dust-free containers.

\section{NATIVE GEL ELECTROPHORESIS OF ${ }^{32}$ P-LABELED RNA}

This protocol was developed to separate different structural forms of a 657-nt self-splicing RNA (Emerick and Woodson, 1994). The protocol can be adapted to shorter transcripts by increasing the percentage of the polyacrylamide gel. Once the best conditions for separating the conformers of interest have been determined, this protocol is used to prepare the RNA for further analysis as described in Basic Protocols 2 and 3.

\section{Materials}

$70 \%$ ethanol

$40 \%$ (w/v) 29:1 acrylamide/bisacrylamide, $4^{\circ} \mathrm{C}$

$10 \times$ THEM buffer (see recipe)

$10 \%(\mathrm{w} / \mathrm{v})$ ammonium persulfate, $4^{\circ} \mathrm{C}$

TEMED, $4^{\circ} \mathrm{C}$
BASIC

PROTOCOL 1

RNA Folding Pathways

\subsection{1}

Supplement 2 
$5 \times$ splicing buffer (see recipe)

${ }^{32}$ P-labeled RNA, desalted (see Support Protocol 1)

$30 \mathrm{mM} \mathrm{MgCl}{ }_{2}$

$5 \times$ glycerol loading buffer (see recipe)

$20 \times 20-\mathrm{cm}$ glass plates with 0.5 -mm spacers and comb ( 1 or 2 sets)

Vacuum source and 50-mL side-arm flask (for degassing)

$20 \times 20-\mathrm{cm}$ vertical gel electrophoresis apparatus with recirculating cooling reservoir (e.g., Owl Scientific Penguin 10DS or equivalent)

Refrigerated recirculating bath to connect to gel apparatus

Spatula or razor blade

3MM filter paper (Whatman)

Vacuum gel drying apparatus

$\mathrm{X}$-ray film for autoradiography or phosphorescent imager

CAUTION: Acrylamide and $N, N^{\prime}$-methylenebisacrylamide are neurotoxins and suspected carcinogens. Preparation of solutions with these compounds should be performed in a well-ventilated fume hood, and extreme precautions taken to minimize contact with solids or solutions.

\section{Cast native $6 \%$ polyacrylamide gel}

1. Thoroughly clean two glass plates and remove any streaks with $70 \%$ ethanol.

2. Assemble glass plates, placing 0.5 -mm spacers between glass on each side. Clamp the sides of the sandwich with aluminum binder clamps and seal bottom with tape.

The bottom of plates may be left open. The gel solution will be retained by capillary action.

3. Mix the following in a graduated cylinder ( $25 \mathrm{~mL}$ total volume per gel):

$3.75 \mathrm{~mL} \mathrm{40 \%} \mathrm{29:1} \mathrm{acrylamide/bisacrylamide}$

$2.5 \mathrm{~mL} 10 \times$ THEM buffer

$250 \mu \mathrm{L} 10 \%$ ammonium persulfate

Deionized water up to $25 \mathrm{~mL}$.

4. Transfer to 50-mL side-arm flask and degas mixture by swirling 1 to 3 min under a gentle vacuum (water aspirator).

5. Add $16 \mu \mathrm{L}$ TEMED and swirl to initiate polymerization. Immediately pour solution into the top of the casting frame while holding glass plates at a very slight incline with respect to the bench.

It is important to pour the solution evenly to avoid introducing bubbles.

6. Insert comb into top of frame to form desired number of sample wells; allow gel to polymerize in a horizontal position (i.e., $\sim 20 \mathrm{~min}$ ).

\section{Pre-run gel}

7. Remove comb, flushing wells with water or running buffer. Remove any tape from bottom of gel. Place gel on electrophoresis apparatus as instructed by manufacturer.

8. Prepare $1 \times$ THEM buffer by diluting $10 \times$ stock with deionized water. Add sufficient $1 \times$ THEM buffer to upper and lower chambers to cover top and bottom of gel.

9. Pre-run at $15 \mathrm{~W}$ per gel for 15 to $30 \mathrm{~min}$. Adjust temperature of circulating bath to maintain surface of plates at $10^{\circ} \mathrm{C}$. 
Prechilling the bath decreases the time required for gel to reach desired temperature. Bath temperatures of $-5^{\circ}$ to $0^{\circ} \mathrm{C}$ may be required to cool gel sufficiently; add $50 \%$ ethylene glycol to bath to prevent freezing.

CAUTION: Personnel should be shielded from $\beta$ radiation during steps 10 to 14 .

\section{Prepare and load RNA samples}

10. Add the following to a $0.5-\mathrm{mL}$ microcentrifuge tube ( $8 \mu \mathrm{L}$ total volume):

$$
\begin{aligned}
& 2 \mu \mathrm{L} 5 \times \text { splicing buffer } \\
& 1 \mu \mathrm{L}{ }^{32} \mathrm{P} \text {-labeled RNA }(100,000 \mathrm{cpm}) \\
& 5 \mu \mathrm{L} \text { deionized } \mathrm{H}_{2} \mathrm{O} .
\end{aligned}
$$

11. Place $2 \mu \mathrm{L}$ of $30 \mathrm{mM} \mathrm{MgCl}_{2}$ on lid of microcentrifuge tube and close firmly.

The drop of buffer will remain on the lid by surface tension.

12. To renature RNA, place closed tube in a heating block at $95^{\circ} \mathrm{C}$ for $1 \mathrm{~min}$. Transfer to microcentrifuge and immediately spin for $1 \mathrm{~min}$. Place on ice.

For unrenatured RNA samples, omit the incubation at $95^{\circ} \mathrm{C}$.

The drop of $\mathrm{MgCl}_{2}$ will mix with the warm RNA solution at the bottom of the tube during centrifugation. This procedure minimizes metal ion-catalyzed hydrolysis of the RNA during the high-temperature incubation. Place the heating block next to the microcentrifuge to minimize the time required to transfer the samples.

13. Add $2.5 \mu \mathrm{L}$ of $5 \times$ glycerol loading buffer and mix well. Place samples on ice.

14. Load $2 \mu \mathrm{L}$ of each sample into wells of native gel and run at $15 \mathrm{~W}$ per gel for 5 to 6 hr at $10^{\circ} \mathrm{C}$.

For the best resolution, the sample should be no more than 2 to $3 \mathrm{~mm}$ deep after loading.

The electrophoresis time will vary with the size of the RNA and the percentage of polyacrylamide. Gels are typically run until xylene cyanol FF is at the bottom of the gel or beyond.

\section{Detect ${ }^{32}$ P-labeled bands of RNA}

15. Unclamp gel from apparatus and remove spacers. Gently pry the glass plates apart with a thin spatula or razor blade and remove one glass plate.

Do this step as soon as the run is complete.

16. Transfer gel from the second glass plate to dry Whatman 3MM filter paper cut a little larger than the gel. Cover completely with plastic wrap, and dry 15 to 30 min under vacuum using a heated gel-drying apparatus.

Do not do this step if planning to do two-dimensional gel electrophoresis (Basic Protocol 2).

17. Expose dried gel to X-ray film or a phosphorescent screen overnight to obtain an image of the radioactive bands.

\section{ASSAY OF CATALYTIC ACTIVITY BY TWO-DIMENSIONAL GEL ELECTROPHORESIS}

Following separation of RNA conformers by native gel electrophoresis (see Basic Protocol 1), the catalytic activity of each species is determined by addition of substrate while the RNA is immobilized in the gel matrix. The products are analyzed by two-dimensional electrophoresis under denaturing conditions (Branch et al., 1989). The spliced products are detected as shorter RNAs on the denaturing gel.

BASIC PROTOCOL 2

RNA Folding Pathways 


\section{Materials}

$0.1 \mathrm{mM}$ GTP in splicing buffer (see recipe)

$2 \times$ urea loading buffer (see recipe)

40\% (w/v) 29:1 acrylamide/bisacrylamide, $4^{\circ} \mathrm{C}$

$10 \times$ TBE buffer (APPENDIX 2A)

Urea

$10 \%(\mathrm{w} / \mathrm{v})$ ammonium persulfate

TEMED

Bed of ice (size of gel)

X-ray film

Razor blades

Glass plates (e.g., $20 \times 20 \mathrm{~cm}$ or larger)

Additional reagents and equipment for native gel electrophoresis (see Basic

Protocol 1)

\section{Excise samples from native polyacrylamide gel (first dimension)}

1. Separate RNA conformers by native gel electrophoresis (see Basic Protocol 1, steps 1 to 15 ). In step 10 , use $\geq 500,000 \mathrm{cpm}$ per sample and reduce the volumes by half (i.e., total $5 \mu \mathrm{L}$ ). Load 3 to $5 \mu \mathrm{L}$.

Skipping wells or leaving a large space between lanes will make it easier to excise the bands from gel without cross-contamination in step 4.

2. After removing top glass plate, cover gel with plastic wrap. Place gel (glass side down) on a bed of ice.

The gel should be maintained on ice when possible during the following steps to retard diffusion of the RNA in the gel. Steps 3 to 5 should be performed as quickly as possible.

3. In a darkroom or light-tight box, place a sheet of X-ray film on gel for 2 to $15 \mathrm{~min}$. Mark gel and film for realignment. Develop film after the desired time.

4. Align gel (glass side down) over the autoradiogram. Using the autoradiogram to locate the RNA, excise each lane with a new razor blade, being certain to include the entire region of the lane that contains the bands of interest.

Invert an acrylic radiation shield over gel to block ${ }^{32} P$ radiation and protect samples from airborne ribonucleases.

The gel pieces should be $\sim 0.6 \times 4 \mathrm{~cm}$.

5. Transfer gel pieces to a glass plate (e.g., $20 \times 20 \mathrm{~cm}$ or larger), laying them horizontally along the bottom edge as shown in right panel of Figure 11.4.1.

Forceps should be RNase-free or flamed with ethanol just before use.

\section{Perform self-splicing in situ}

6. Pipet $5 \mu \mathrm{L}$ of $0.1 \mathrm{mM} \mathrm{GTP}$ in splicing buffer as evenly as possible over the surface of each gel piece. Allow to stand $2 \mathrm{~min}$ at room temperature.

7. Add $10 \mu \mathrm{L}$ of $2 \times$ urea loading buffer.

Urea quenches the self-splicing reaction.

Probing RNA Folding Pathways by RNA Fingerprinting

\section{Assemble and run denaturing polyacrylamide gel (second dimension)}

8. Complete assembly of gel frame for the second-dimension electrophoresis by placing spacers on each side and a second glass plate on top of samples from step 7. Clamp sides of frame and seal bottom with tape. 


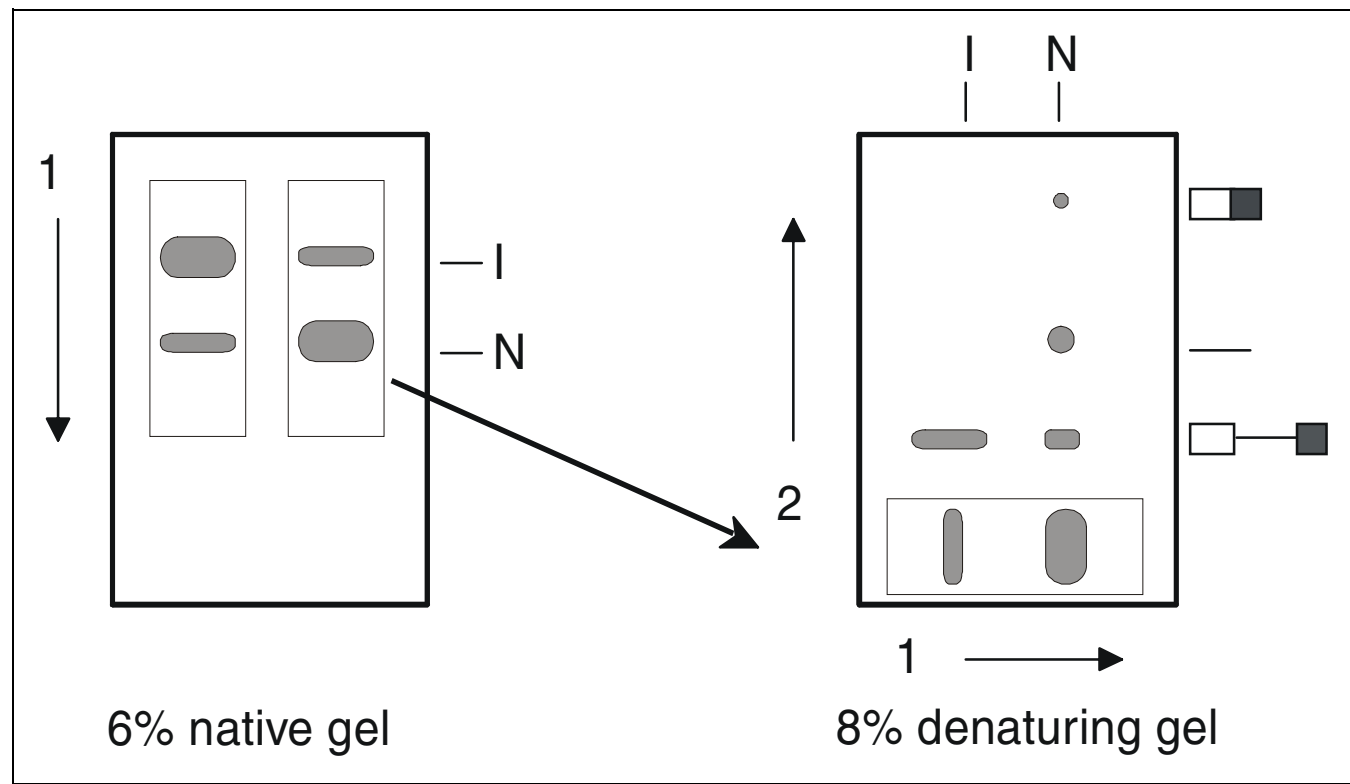

Figure 11.4.1 Two-dimensional gel electrophoresis of self-splicing RNA. After native gel electrophoresis (first dimension), the lane is excised and placed on the bottom of the second casting frame. The active form of the RNA $(N)$ is spliced when GTP substrate is added to the gel slice. The products are resolved in a denaturing polyacrylamide gel (second dimension).

It may be necessary to use spacers that are slightly thicker than those used for the first-dimension gel to avoid squashing the gel pieces.

9. Prepare solution for an $8 \%$ denaturing sequencing gel $(25 \mathrm{~mL}$ total volume for 0.5 $\mathrm{mm} \times 20 \times 20 \mathrm{~cm})$.

$5 \mathrm{~mL} \mathrm{40 \%} \mathrm{29:1} \mathrm{acrylamide/bisacrylamide}$

$2.5 \mathrm{~mL} 10 \times$ TBE buffer

$12 \mathrm{~g}$ urea

Deionized water up to $25 \mathrm{~mL}$.

Dissolve urea at 50 to $65^{\circ} \mathrm{C}$. Transfer to a sidearm flask and degas.

10. Add $0.5 \mathrm{~mL}$ of $10 \%$ ammonium persulfate and $20 \mu \mathrm{L}$ TEMED to begin polymerization.

11. Immediately pour solution into gel frame from top, allowing solution to run slowly down the side and then across the bottom, covering gel slices without introducing air bubbles.

It is not necessary to insert a comb in the top of gel.

12. After gel has polymerized, clamp it on gel box with first-dimension samples at the bottom. Add 1× TBE buffer to upper and lower reservoirs.

13. Connect the positive electrode to top of gel and the negative electrode to the bottom.

The gel is run in reverse so that the RNA migrates from bottom to top.

14. Run at 25 to $30 \mathrm{~W}\left(40^{\circ}\right.$ to $\left.50^{\circ} \mathrm{C}\right)$ until the xylene cyanol has run off the top of gel.

15. Disassemble, dry, and expose gel to X-ray film (see Basic Protocol 1, steps 15 to 17).

RNA Folding Pathways 


\section{GELS}

As an alternative to two-dimensional electrophoresis, the molecular weight of the RNAs in a native gel band may be determined by eluting the RNA from the gel matrix. The activity of the conformer can be determined by adding substrate to the gel slice before eluting the RNA. After elution, the RNA is concentrated by ethanol precipitation and analyzed on a denaturing polyacrylamide gel.

Additional Materials (also see Basic Protocols 1 and 2)

TEN buffer (see recipe)

$10 \mathrm{mg} / \mathrm{mL}$ carrier tRNA (Sigma)

$70 \%$ and $100 \%$ ethanol, $-20^{\circ} \mathrm{C}$

TE buffer, $\mathrm{pH} 7.5$ (APPENDIX 2A)

Rocker or orbital mixer

$4 \%$ to $6 \%$ denaturing polyacrylamide gel (see Basic Protocol 2)

\section{Recover RNA from native polyacrylamide gel}

1. Separate RNA conformers by native gel electrophoresis (see Basic Protocol 1, steps 1 to 14$)$, using $200,000 \mathrm{cpm}\left[{ }^{32} \mathrm{P}\right] \mathrm{RNA}$ per sample.

2. Excise bands of RNA from native gel (see Basic Protocol 2, steps 1 to 4). Instead of excising the entire lane, individually remove each band to be analyzed and place in separate 1.5 - or $2-\mathrm{mL}$ microcentrifuge tubes.

3. Place 1 to $2 \mu \mathrm{L}$ of $0.1 \mathrm{mM}$ GTP in splicing buffer on gel slice and incubate for $2 \mathrm{~min}$, room temperature. Add 2 to $4 \mu \mathrm{L}$ of $2 \times$ urea loading buffer.

It is useful to prepare control samples, in which this step is omitted, to determine whether any splicing occurred before native gel electrophoresis.

4. Freeze excised gel slices on dry ice 1 to $5 \mathrm{~min}$. Thaw at room temperature or in a $25^{\circ} \mathrm{C}$ water bath.

A freeze/thaw cycle improves recovery of RNA.

5. Add a sufficient volume of TEN buffer to cover gel piece (e.g., 0.3 to $0.6 \mathrm{~mL}$ ). Place tightly sealed tubes on a rocker or orbital shaker and soak overnight at $4{ }^{\circ} \mathrm{C}$.

In some cases, 30 to 60 min at $65^{\circ} \mathrm{C}$ improves recovery of $R N A$.

6. Microcentrifuge $1 \mathrm{~min}$ at $10,000 \times g$, room temperature. Carefully transfer supernatant to a clean tube.

Avoid transfering pieces of polyacrylamide.

Solution may be filtered using a small spin-filtration device $(0.45 \mathrm{~mm})$ that is nuclease free.

7. Add a small amount of TEN buffer (e.g., 50 to $100 \mu \mathrm{L}$ ) to gel slices, mix thoroughly, and remove as in step 6. Pool supernatants.

Elution of radiolabeled RNA from gel is easily checked using a standard survey meter.

\section{Concentrate RNA by ethanol precipitation}

8. Precipitate RNA by adding $1 \mu \mathrm{L}$ of $10 \mathrm{mg} / \mathrm{mL}$ carrier tRNA and three volumes ice-cold $100 \%$ ethanol to supernatants. Chill at $-20^{\circ} \mathrm{C} 1$ to $2 \mathrm{hr}$ or overnight, or at $-70^{\circ} \mathrm{C}$ for $10 \mathrm{~min}$.

9. Recover RNA by microcentrifuging 20 to $30 \mathrm{~min}$ at $10,000 \times g, 4^{\circ} \mathrm{C}$. Discard supernatant with a pipet, being careful to avoid pellet. 
10. Wash pellet with $70 \%$ ethanol and dry under vacuum.

Analyze RNA by denaturing polyacrylamide gel electrophoresis

11. Dissolve dried pellets in $2 \mu \mathrm{L}$ water and add $2 \mu \mathrm{L}$ of $2 \times$ urea loading buffer.

Adjust volumes as required so that the concentration of ${ }^{32} \mathrm{P}$ in each sample is approximately equal.

12. Prepare one or more reference samples by diluting the original RNA sample (or molecular weight markers) in TE buffer, $\mathrm{pH} 7.5$, so that the concentration of radioactivity matches that of the samples in step 11 . Add an equal concentration of $2 \times$ urea loading buffer.

13. Load $4 \mu \mathrm{L}$ of each sample into the wells of a $20 \times 20-\mathrm{cm} 4 \%$ to $6 \%$ denaturing polyacrylamide gel (see Basic Protocol 2, steps 9 to 10 ) and run at $30 \mathrm{~W}, 50^{\circ} \mathrm{C}$, until xylene cyanol FF tracking dye reaches the bottom.

Samples may be heated 1 min at $80^{\circ} \mathrm{C}$ before loading if desired.

\section{CHEMICAL MODIFICATION OF RNA IN A NATIVE POLYACRYLAMIDE GEL}

After native gel electrophoresis, RNA is modified in situ by dimethyl sulfate (DMS) or kethoxal. DMS reacts with unpaired adenosines (N1) and cytosines (N3). Kethoxal reacts with the $\mathrm{N} 1$ and $\mathrm{N} 2$ of unpaired guanosines. The position of the modified bases is determined by primer extension with reverse transcriptase.

Additional Materials (also see Basic Protocols 1 and 2 and Alternate Protocol)

Unlabeled RNA (see Support Protocol 2; see also UNIT 6.1)

Dimethyl sulfate (DMS, Aldrich; obtain fresh and store at $-20^{\circ} \mathrm{C}$ )

$50 \%$ and $100 \%$ ethanol

Stop buffer A (see recipe)

$70 \mathrm{mg} / \mathrm{mL}$ kethoxal (ICN Biochemicals or Research Organics) in 20\% ethanol (store at $-20^{\circ} \mathrm{C}$ )

Stop buffer B (see recipe)

Buffered phenol (APPENDIX 2A)

24:1 (v/v) chloroform/isoamyl alcohol

Additional reagents and equipment for primer extension (see Support Protocol 3) and for sequencing gels (UNIT 6.1 and APPENDIX 3B)

CAUTION: Dimethyl sulfate (DMS) is a carcinogen and should be handled in a fume hood with gloves that are impermeable to nonpolar solvents.

\section{Separate RNA conformers by native gel electrophoresis}

1. Prepare a native gel (see Basic Protocol 1, steps 1 to 9).

2. Prepare 2 samples of ${ }^{32} \mathrm{P}$-labeled RNA $(500,000 \mathrm{cpm})$ in $10 \mu \mathrm{L}$ splicing buffer (see Basic Protocol 1, steps 10 to 12).

3. Prepare 3 samples containing 2 pmol each unlabeled RNA in the same manner.

4. Load samples into adjacent wells of a native polyacrylamide gel (see Basic Protocol 1 , steps 13 to 15). When electrophoresis is complete, disassemble gel and obtain an autoradiogram (see Basic Protocol 2, steps 2 and 3).

RNA Folding Pathways

11.4.7 
5. Using the position of labeled RNA in the autoradiogram as a guide, excise the regions of adjacent lanes containing unlabeled RNA that contain the bands of interest (see Basic Protocol 2, step 2).

This step and all subsequent steps are carried out on ice.

6. Transfer each gel slice (containing a single band) to a separate 1.5- or 2-mL microcentrifuge tube.

There should be three duplicate sets of gel slices containing unlabeled RNA.

\section{Modify RNA with DMS}

7. Dilute DMS 1:40 in 50\% ethanol. Add $20 \mu \mathrm{L}$ diluted DMS to each slice originating from one lane of native gel. Distribute as evenly as possible over the surface. Incubate 0.5 to $2 \mathrm{~min}$ on ice.

The concentration of DMS should be adjusted so that an even ladder of primer extension products is obtained in steps 16 to 19.

8. Quench reaction with $300 \mu \mathrm{L}$ stop buffer A.

\section{Modify RNA with kethoxal}

9. Apply $20 \mu \mathrm{L}$ of $70 \mathrm{mg} / \mathrm{mL}$ kethoxal to each gel piece from a second lane of the native gel. Incubate 3 to $8 \mathrm{~min}$ on ice.

The incubation time should be adjusted as above.

10. Quench reaction with $300 \mu \mathrm{L}$ stop buffer B.

\section{Elute RNA from gel}

11. Add $300 \mu \mathrm{L}$ stop buffer B to each gel piece from the third lane of the native gel.

These will serve as unmodified controls.

12. Soak gel pieces several hours or overnight at $4^{\circ} \mathrm{C}$. Recover RNA (see Alternate Protocol, steps 5 to 6).

13. Extract supernatants once with an equal volume of buffered phenol. Microcentrifuge $1 \mathrm{~min}$ at $10,000 \times g, 4^{\circ} \mathrm{C}$, to separate layers and carefully transfer all of upper aqueous phase to a clean microcentrifuge tube.

14. Extract aqueous phases with $24: 1$ chloroform/isoamyl alcohol and transfer upper aqueous phase to a new set of microcentrifuge tubes.

15. Precipitate RNA with 3 volumes of $100 \%$ ethanol and dry pellets (see Alternate Protocol, steps 8 to 10).

RNA may be stored at $-20^{\circ} \mathrm{C}$ as an ethanol suspension or as a dried pellet for up to a week.

\section{Detect modified bases by primer extension}

16. Dissolve RNA pellets in 2 to $10 \mu \mathrm{L}$ water, so that their concentrations are roughly equal (neglecting any carrier RNA that may have been added).

The relative amount of RNA present in each band of native gel can be estimated by quantifying distribution of radioactive samples in step 4.

Probing RNA Folding Pathways by RNA Fingerprinting

17. Perform primer extension using AMV-RT (see Support Protocol 3).

RNA that was not subjected to native gel electrophoresis can be used as a template for dideoxynucleotide sequencing reactions. 
If sufficient RNA is recovered from the native gel, each sample can be divided into aliquots and used for several primer extension reactions.

18. Separate primer extension products on a $6 \%$ or $8 \%$ polyacrylamide sequencing gel (APPENDIX 3B).

19. Detect primer extension products by autoradiography or by using a phosphorescent imaging screen. Compare primer extension pattern of modified RNAs to unmodified controls to determine which bands are specific for reactions with DMS or kethoxal. Determine relative intensity of specific primer extension bands for each RNA conformer by comparing products of RNA samples that were recovered from different regions of the native gel.

Differences in the extent of modification may be quantified using a phosphorimager or densitometer.

\section{IN VITRO SYNTHESIS OF ${ }^{32}$ P-LABELED PRE-RNA WITH T7 RNA POLYMERASE}

Uniformly radiolabeled pre-RNA is prepared by run-off transcription of plasmid DNA or oligonucleotide templates (Milligan and Uhlenbeck, 1980) with purified phage T7 RNA polymerase (Davanloo et al., 1984). The template DNA must be cleaved downstream of the desired RNA sequence with a restriction enzyme. Transcription is carried out for short times (i.e., 20 to $30 \mathrm{~min}$ ) at $30^{\circ} \mathrm{C}$ to minimize self-splicing (Emerick and Woodson, 1993).

\section{Materials}

$1 \mu \mathrm{g} / \mu \mathrm{L}$ plasmid DNA containing a T7 promoter, digested with appropriate restriction enzyme(s) (e.g. Feinbaum, 2000; Tabor, 2000)

$10 \times$ T7 RNAP buffer (see recipe)

$20 \mathrm{mM}$ spermidine $\cdot \mathrm{HCl}$ (store at $-20^{\circ} \mathrm{C}$ )

$10 \times$ NTPs "low A" (see recipe)

10 to $20 \mu \mathrm{Ci}\left[\alpha-{ }^{32} \mathrm{P}\right] \mathrm{ATP}$ (store at $-20^{\circ} \mathrm{C}$ )

500 to $1000 \mathrm{U} / \mu \mathrm{L} \mathrm{T} 7 \mathrm{RNA}$ polymerase (store at $-20^{\circ} \mathrm{C}$ )

TE buffer, $\mathrm{pH} 7.5$ (APPENDIX 2A) or another buffer

$30^{\circ} \mathrm{C}$ water bath

Gel-filtration spin column (e.g., TE-100, Clontech), $4^{\circ} \mathrm{C}$

Liquid scintillation counter

Scintillation fluid and vials

NOTE: Buffers and reagents should be kept on ice after thawing. Steps 1 to 4 are carried out at $4{ }^{\circ} \mathrm{C}$ except where noted.

\section{Transcribe RNA}

1. Add the following to a $1.5-\mathrm{mL}$ microcentrifuge tube ( $40 \mu \mathrm{L}$ total volume):

$1 \mu \mathrm{L} 1 \mu \mathrm{g} / \mu \mathrm{L}$ digested plasmid DNA

$4 \mu \mathrm{L} 10 \times$ T7 RNAP buffer

$4 \mu \mathrm{L} 20 \mathrm{mM}$ spermidine $\cdot \mathrm{HCl}$

$4 \mu \mathrm{L} 10 \times$ NTPs "low A"

1 to $2 \mu \mathrm{L} 10 \mu \mathrm{Ci} / \mu \mathrm{L}\left[\alpha_{-}{ }^{32} \mathrm{P}\right] \mathrm{ATP}$

25 to $24 \mu \mathrm{L} \mathrm{H}_{2} \mathrm{O}$.

For RNAs that are not self-splicing, the additional spermidine should be omitted.

RNA Folding

Pathways 
2. Mix gently by tapping with finger. Spin briefly in a microcentrifuge to bring contents to the bottom of tube, if necessary.

3. Add $1 \mu \mathrm{l}$ of 500 to $1000 \mathrm{U} / \mu \mathrm{L}$ T7 RNA polymerase. Mix well.

4. Incubate at $30^{\circ} \mathrm{C}$ for 20 to $30 \mathrm{~min}$.

Short reaction times reduce accumulation of spliced products. For RNAs that do not self-cleave, better yields will be obtained by incubating $1 \mathrm{hr}$ at $37^{\circ} \mathrm{C}$.

\section{Remove unincorporated nucleotide triphosphates}

5. While the transcription reaction is proceeding, prepare a spin column at room temperature for each sample. Pre-equilibrate column with TE buffer, $\mathrm{pH} 7.5$ (or another buffer). After the column has drained, spin $3 \mathrm{~min}$ at $3000 \times \mathrm{g}$, room temperature, to remove all excess buffer. Avoid trapping air bubbles in column matrix.

Drain column in clean microcentrifuge tube and avoid touching tip.

6. When transcription reaction is complete, immediately load entire sample onto top of spin column.

7. Spin 5 min at $3000 \times g$, room temperature, using a clean RNase-free tube to collect sample.

8. Discard column as solid radioactive waste.

9. Determine the yield of RNA by counting 1 or $2 \mu \mathrm{L}$ eluate in a liquid scintillation counter. Place RNA on ice, or store at $-20^{\circ} \mathrm{C}$.

One should obtain approximately $10^{5} \mathrm{cpm} / \mu \mathrm{L}$.

The RNA may also be purified by denaturing gel electrophoresis.

SUPPORT PROTOCOL 2

Probing RNA Folding Pathways by RNA Fingerprinting

\section{LARGER SCALE IN VITRO SYNTHESIS OF UNLABELED PRE-RNA WITH T7 RNA POLYMERASE}

Larger quantities (i.e., 0.5 to $2 \mathrm{nmol}$ ) of unlabeled RNA may prepared by increasing the scale of in vitro transcription reactions. Abortive initiation products and unincorporated nucleotide triphosphates are removed by gel-filtration chromatography. For some applications, self-splicing products must be removed by preparative polyacrylamide gel electrophoresis.

\section{Materials}

$1 \mu \mathrm{g} / \mu \mathrm{L}$ digested plasmid DNA (10 $\mu \mathrm{g}$ total)

$10 \times$ T7 RNAP buffer (see recipe)

$1 \mathrm{M}$ spermidine $\cdot \mathrm{HCl}$

50 or $100 \mathrm{mM}$ each of ATP, CTP, GTP, and UTP

500 to $1000 \mathrm{U} / \mu \mathrm{L}$ T7 RNA polymerase

0.5 M EDTA (APPENDIX 2A)

$3 \mathrm{M}$ sodium acetate, $\mathrm{pH} 5.0$ (APPENDIX 2A)

$100 \%$ ethanol

G-50 gel-filtration chromatography resin (see recipe)

TEN buffer (see recipe)

15-mL sterile polypropylene culture tubes

Empty 10-mL disposable column with frit (e.g., Pharmacia Biotech PD-10 or BioRad Econo column) 
1. Add the following to a $15-\mathrm{mL}$ sterile culture tube ( $2 \mathrm{~mL}$ total volume):

$10 \mu \mathrm{L} 1 \mu \mathrm{g} / \mu \mathrm{L}$ digested plasmid DNA

$200 \mu \mathrm{L} 10 \times$ T7 RNAP buffer

$1 \mu \mathrm{L} 1 \mathrm{M}$ spermidine $\cdot \mathrm{HCl}$

$20 \mu \mathrm{L}$ each of $100 \mathrm{mM}$ ATP, CTP, GTP, and UTP (1 mM each NTP final)

$1.70 \mathrm{~mL} \mathrm{H}_{2} \mathrm{O}$.

For RNAs that are not self-splicing, spermidine should be omitted.

2. Mix thoroughly by vortexing. Centrifuge briefly in a benchtop centrifuge to bring contents to bottom of tube.

3. Add $10 \mu \mathrm{T}$ T7 RNA polymerase. Mix well (do not vortex).

4. Incubate $1 \mathrm{hr}$ at $30^{\circ} \mathrm{C}$.

Non-self-cleaving RNAs may be transcribed over $2 \mathrm{hr}$ at $37^{\circ} \mathrm{C}$.

5. Add the following and mix well,

$5 \mu \mathrm{L} 0.5$ M EDTA

$0.2 \mathrm{~mL} 3 \mathrm{M}$ sodium acetate, $\mathrm{pH} 5.0$

$6 \mathrm{~mL} 100 \%$ ethanol.

Chill $2 \mathrm{hr}$ or overnight at $-20^{\circ} \mathrm{C}$.

\section{Remove unincorporated nucleotide triphosphates}

6. Recover RNA by centrifuging $30 \mathrm{~min}$ at $12,700 \times g(9000 \mathrm{rpm}$ in a Beckman JS13.1 rotor), $4^{\circ} \mathrm{C}$. Drain pellet and dry completely under vacuum.

7. Resuspend pellet in 100 to $300 \mu \mathrm{L}$ TEN buffer.

If pellet does not dissolve easily, carefully disrupt solid material using the end of a disposable, nuclease-free pipet.

8. To prepare gel-filtration column, clamp empty $10-\mathrm{mL}$ column body to ring stand or buret holder. Place a beaker underneath to catch effluent.

9. Pipet slurry of equilibrated G-50 resin into column, allowing buffer to drain freely as resin settles. Continue to add slurry until the bed volume is $10 \mathrm{~mL}$.

The column should be free of discontinuities or air bubbles.

Pre-packed columns (5- to 10-mL) may be substituted if commercially available.

10. Wash column with an additional 2 to $3 \mathrm{~mL}$ TEN buffer. Allow buffer to drain until just level with the top of the column. Stop the flow by placing tight-fitting cover over the bottom tip of the column.

The flow rate should be $\sim 0.5 \mathrm{~mL} / \mathrm{min}$. The column must not be allowed to run dry.

11. Apply sample to a pre-equilibrated gel-filtration column and elute with additional TEN buffer. After the void volume $(\sim 3 \mathrm{~mL})$, collect eluate in ten 0.5 - $\mathrm{mL}$ fractions.

12. Determine absorbance of fractions at $260 \mathrm{~nm}$ (dilute 100-fold), and pool the peak fractions.

The RNA should elute in the first 2 to 4 fractions after the void volume.

13. Recover the nucleic acid from pooled fractions by ethanol precipitation and determine final yield from absorbance at $260 \mathrm{~nm}$.

RNA Folding Pathways

11.4.11 
SUPPORT PROTOCOL 3
Probing RNA Folding Pathways by RNA

Fingerprinting

\section{DETECTION OF MODIFIED BASES BY PRIMER EXTENSION}

The positions of modified bases are determined by extension of a ${ }^{32} \mathrm{P}$-labeled primer with reverse transcriptase using the modified RNA from Basic Protocol 3 as a template. Positions of the modified bases are determined by running the primer extension reactions on a sequencing gel and comparing to sequencing lanes prepared using ddNTPs for chain termination. Differences in the secondary and tertiary structure of the RNA conformers probed in Basic Protocol 3 can be determined by comparing the intensities of the termination products. Refer to UNIT 6.1 for an alternate protocol and more comprehensive discussion of primer extension methods.

\section{Additional Materials (also see Basic Protocols 1 and 3)}

$5 \times$ annealing buffer (see recipe)

$1 \mathrm{pmol} / \mu \mathrm{L} 5^{\prime}{ }^{32} \mathrm{P}$-labeled sequencing primer (UNIT 6.1)

Diluted RNA for primer extension (see Basic Protocol 3)

Unmodified RNA (see Support Protocol 2)

$5 \times$ ddATP, ddCTP, ddGTP, and ddTTP solutions, prepared separately at $0.4 \mathrm{mM}$ in $1 \times$ annealing buffer

$5 \times$ RT buffer (see recipe)

Avian myoblastosis virus reverse transcriptase (AMV-RT; Life Sciences or Seikageiku America)

$5 \times 4 \mathrm{dNTP}$ mix: $2 \mathrm{mM}$ each of dATP, dCTP, dGTP, and dTTP combined in $1 \times$ annealing buffer

$2 \times$ formamide loading buffer (see recipe)

$48^{\circ}$ and $65^{\circ} \mathrm{C}$ water baths or heating blocks

Additional reagents and equipment for preparing and running $6 \%$ or $8 \%$ polyacrylamide sequencing gel (APPENDIX $3 B$ )

NOTE: The following steps are carried out on ice except where indicated. Thawed reagents should kept on ice throughout.

\section{Anneal complementary primer to RNA}

1. Prepare primer cocktail (total $20 \mu \mathrm{L}$ ) by mixing the following:

$4 \mu \mathrm{L} 5 \times$ annealing buffer

$8 \mu \mathrm{L} 1 \mathrm{pmol} / \mu \mathrm{L} 5^{\prime 32} \mathrm{P}$-labeled sequencing primer

$8 \mu \mathrm{L}$ deionized water.

Volumes given are for 20 reactions and can be adjusted as needed.

2. For each extension reaction, add $1 \mu \mathrm{L}$ primer cocktail ( 0.4 pmol primer) to $2 \mu \mathrm{L}$ diluted RNA (see Basic Protocol 3, step 16) in a $0.5-\mathrm{mL}$ microcentrifuge tube.

It is often helpful to carry out control reactions using 0.1 to 0.5 pmol RNA that has been modified with DMS or kethoxal in solution (UNIT 6.1).

3. Heat $3 \mathrm{~min}$ in a water bath or heating block at $65^{\circ} \mathrm{C}$ and place immediately on ice. Microcentrifuge briefly at maximum speed before opening tubes. Keep samples on ice.

Better results are obtained with some primer/template combinations by heating 2 min at $80^{\circ} \mathrm{C}$.

\section{Prepare sequencing reactions}

4. Mix the following in a $0.5-\mathrm{mL}$ tube: 
2 pmol unmodified RNA

$2 \mu \mathrm{L} 5 \times$ annealing buffer

$2 \mu \mathrm{L} 1 \mathrm{pmol} / \mu \mathrm{L} 5^{\prime 32} \mathrm{P}$-labeled primer

deionized water to $10 \mu \mathrm{L}$.

5. Anneal primer as in step 3.

6. Divide the annealing reaction from step 5 into five $2-\mu \mathrm{L}$ aliquots. To each aliquot add $1 \mu \mathrm{L}$ of one the following: $1 \times$ annealing buffer, $5 \times$ ddATP, $5 \times$ ddCTP, $5 \times$ ddGTP, and $5 \times$ ddTTP.

The four reactions containing dideoxynucleotide triphosphates serve as sequencing lanes; the reaction containing only buffer serves as a blank. The blank should have no visible bands on the sequencing gel, unless the RNA is partially degraded or has strong secondary structure that causes the reverse transcriptase to terminate.

\section{Extend primer with reverse transcriptase}

7. Prepare a RT cocktail by mixing the following:

$6 \mu \mathrm{L} 5 \times$ RT buffer

$23 \mu \mathrm{L}$ deionized water

$1 \mu \mathrm{L}$ AMV-RT (25 to $50 \mathrm{U})$.

Add the enzyme last. Resuspend enzyme thoroughly in the buffer, but do not vortex and avoid foaming.

8. Add $30 \mu \mathrm{L}$ of $5 \times 4 \mathrm{dNTP}$ mix (total $60 \mu \mathrm{L}$ ) and mix gently.

9. Begin primer extension by adding $2 \mu \mathrm{L}$ RT cocktail to each $3 \mu \mathrm{L}$ annealing reaction (steps 3 and 6). Immediately place each tube in a water bath at $48^{\circ} \mathrm{C}$. Incubate 15 $\min$.

10. Stop reactions by adding $5 \mu \mathrm{L}$ of $2 \times$ formamide loading buffer.

Samples are now ready to be analyzed on a sequencing gel (see Basic Protocol 3, steps 18 and 19). Samples may be stored at $-20^{\circ} \mathrm{C}$ for one week, if desired.

\section{REAGENTS AND SOLUTIONS}

Use deionized or distilled nuclease-free water in all recipes and protocol steps. To eliminate traces of $R N a s e$ on glassware, rinse in RNase-free water and bake $2 \mathrm{hr}$ or overnight at $150^{\circ} \mathrm{C}$. For common stock solutions, see APPENDIX 2A; for suppliers, see SUPPLIERS APPENDIX.

\section{Annealing buffer, 5×}

$200 \mu \mathrm{L} 1 \mathrm{M}$ Tris.Cl, pH 8.3 (APPENDIX 2A; $250 \mathrm{mM}$ final)

$60 \mu \mathrm{L} 4 \mathrm{M} \mathrm{NaCl}(300 \mathrm{mM}$ final)

$40 \mu \mathrm{L} 1 \mathrm{M}$ dithiothreitol (DTT; $50 \mathrm{mM}$ final)

$500 \mu \mathrm{L}$ deionized water $(800 \mu \mathrm{L}$ total volume $)$

Store up to 6 months at $-20^{\circ} \mathrm{C}$

Formamide loading buffer, $2 \times$

$940 \mu \mathrm{L}$ deionized formamide

$40 \mu \mathrm{L}$ 0.5 M EDTA, pH 8.3 (APPENDIX 2A; $20 \mathrm{mM}$ final)

$20 \mu \mathrm{L} 2 \%(\mathrm{w} / \mathrm{v})$ xylene cyanol

$20 \mu \mathrm{L} 2 \%(\mathrm{w} / \mathrm{v})$ bromphenol blue

Store up to one year at $-20^{\circ} \mathrm{C}$

RNA Folding

Pathways 


\section{G-50 gel-filtration chromatography resin}

Gently disperse $5.5 \mathrm{~g}$ of G-50 M (medium) chromatography resin (Amersham Pharmacia Biotech) in $100 \mathrm{~mL}$ TEN buffer (see recipe). Allow to swell $1 \mathrm{ho} 4 \mathrm{hr}$, room temperature. Swirl mixture, allow to settle, and decant fines (see manufacturer's instructions). Repeat if necessary. Adjust the volume of TEN buffer so that the total volume is $100 \mathrm{~mL}$ or twice that of the settled resin. Autoclave and store indefinitely at room temperature.

\section{Glycerol loading buffer, $5 \times$}

$500 \mu \mathrm{L}$ glycerol

$20 \mu \mathrm{L} 2 \%$ (w/v) xylene cyanol

Bring up to $1 \mathrm{~mL}$ with $\mathrm{H}_{2} \mathrm{O}$

Store up to 1 year at $-20^{\circ} \mathrm{C}$ or 1 month at room temperature

\section{GTP in splicing buffer, $0.1 \mathrm{mM}$}

Dilute a $100 \mathrm{mM}$ stock solution of GTP to $0.1 \mathrm{mM}$ with $1 \times$ splicing buffer (see recipe) containing $6 \mathrm{mM} \mathrm{MgCl}_{2}$. Store in aliquots at $-20^{\circ}$ or $-80^{\circ} \mathrm{C}$.

\section{NTPs “low A," 10×}

Obtain concentrated stocks (e.g., 50 or $100 \mathrm{mM}$ ) of each nucleoside triphosphate (ATP, CTP, GTP, and UTP). These may be prepared by dissolving $100 \mathrm{mg}$ solid in $2 \mathrm{~mL}$ water at $4^{\circ} \mathrm{C}$. Adjust the $\mathrm{pH}$ to 7.0 using small aliquots (i.e., 10 to $50 \mu \mathrm{L}$ ) of concentrated $\mathrm{NaOH}$. The $\mathrm{pH}$ may be monitored with a microelectrode or by spotting $5 \mu \mathrm{L}$ onto calibrated $\mathrm{pH}$ indicator strips. Determine the concentration from the UV absorbance of a 1:1000 dilution, and adjust to the desired final concentration with additional water. Store in aliquots at $-80^{\circ} \mathrm{C}$. To prepare working solution, mix 1.25 $\mu \mathrm{L} 100 \mathrm{mM}$ ATP, $6.25 \mu \mathrm{L} 100 \mathrm{mM}$ CTP, $6.25 \mu \mathrm{L} 100 \mathrm{mM}$ GTP, $6.25 \mu \mathrm{L} 100 \mathrm{mM}$ $\mathrm{UTP}$ and bring final volume to $0.5 \mu \mathrm{L}$ with water. Store at $-20^{\circ} \mathrm{C}$.

Final concentrations are $0.25 \mathrm{mM}$ ATP and $1.25 \mathrm{mM}$ each CTP, GTP, and UTP.

\section{RT (reverse transcriptase) buffer, $5 \times$}

$100 \mu \mathrm{L} 1 \mathrm{M}$ Tris.Cl, pH 8.3 (APPENDIX 2A; $250 \mathrm{mM}$ final)

$30 \mu \mathrm{L} 4 \mathrm{M} \mathrm{NaCl}(300 \mathrm{mM}$ final)

$20 \mu \mathrm{L} 1 \mathrm{M}$ dithiothreitol (DTT; $50 \mathrm{mM}$ final)

$60 \mu \mathrm{L} 1 \mathrm{M}$ magnesium acetate (150 mM final)

$190 \mu \mathrm{L}$ deionized water $(400 \mu \mathrm{L}$ total volume $)$

Store up to 6 months at $-20^{\circ} \mathrm{C}$

\section{Splicing buffer, $5 \times$}

$250 \mu \mathrm{L} 1 \mathrm{M}$ NaHEPES, pH 7.5 (final concentration $250 \mathrm{mM}$ )

$500 \mu \mathrm{L} 1 \mathrm{M}\left(\mathrm{NH}_{4}\right)_{2} \mathrm{SO}_{4}$ (final concentration $500 \mathrm{mM}$ )

$10 \mu \mathrm{L} 0.5 \mathrm{M}$ sodium EDTA, pH 8.3 (APPENDIX $2 A$; final concentration $5 \mathrm{mM}$ )

$240 \mu \mathrm{L}$ distilled $\mathrm{H}_{2} \mathrm{O}$ (total volume $1 \mathrm{~mL}$ )

Store up to 1 year at $-20^{\circ} \mathrm{C}$

\section{Stop buffer A}

$14 \mu \mathrm{L} 2$-mercaptoethanol (final concentration $0.2 \mathrm{M}$ )

$100 \mu \mathrm{L} 3 \mathrm{M}$ sodium acetate (APPENDIX $2 \mathrm{~A}$; final concentration $0.3 \mathrm{M}$ )

$40 \mu \mathrm{L} 0.5 \mathrm{M}$ sodium EDTA, pH 8.3 (APPENDIX 2A; final concentration $20 \mathrm{mM}$ )

$846 \mu \mathrm{L}$ distilled $\mathrm{H}_{2} \mathrm{O}$

Mix well and store up to 3 months at $-20^{\circ} \mathrm{C}$ 
$100 \mu \mathrm{L} 3 \mathrm{M}$ sodium acetate (APPENDIX 2A; final concentration $0.3 \mathrm{M}$ )

$40 \mu \mathrm{L} 0.5 \mathrm{M}$ sodium EDTA, pH 8.3 (APPENDIX 2A; final concentration $20 \mathrm{mM}$ )

$860 \mu \mathrm{L}$ distilled $\mathrm{H}_{2} \mathrm{O}$.

Mix well and store up to 1 year at $-20^{\circ} \mathrm{C}$

T7 RNAP (RNA polymerase) buffer, 10 $\times$

$400 \mu \mathrm{L} 1 \mathrm{M}$ Tris.Cl, pH 7.5 (APPENDIX 2A; final concentration $400 \mathrm{mM}$ )

$150 \mu \mathrm{L} 1 \mathrm{M} \mathrm{MgCl}_{2}$ (APPENDIX $2 A$; final concentration $150 \mathrm{mM}$ )

$20 \mu \mathrm{L} 1 \mathrm{M}$ spermidine $\cdot \mathrm{HCl}$ (final concentration $20 \mathrm{mM}$ )

$50 \mu \mathrm{L} 1 \mathrm{M}$ dithiothreitol (DTT, APPENDIX 2A; final concentration $50 \mathrm{mM}$ )

$380 \mu \mathrm{L}$ distilled $\mathrm{H}_{2} \mathrm{O}$ (total volume $1 \mathrm{~mL}$ )

Mix well and store up to 3 months at $-20^{\circ} \mathrm{C}$

\section{TEN (Tris/EDTA/NaCl) buffer}

$10 \mathrm{mM}$ Tris. Cl, pH 7.5 (APPENDIX 2A)

$1 \mathrm{mM}$ disodium EDTA (APPENDIX 2A)

$250 \mathrm{mM}$ sodium chloride

Autoclave and store indefinitely at room temperature or up to 2 months after opening

THEM (Tris/HEPES/EDTA/MgCl $_{2}$ buffer, 10×, pH 7.4

$157.08 \mathrm{~g}$ HEPES (final concentration $660 \mathrm{mM}$ )

$41.14 \mathrm{~g}$ Tris base (final concentration $340 \mathrm{mM}$ )

$0.36 \mathrm{~g}$ disodium EDTA (final concentration $1 \mathrm{mM}$ )

$20.32 \mathrm{~g} \mathrm{MgCl}_{2}$ (final concentration $100 \mathrm{mM}$ )

$1 \mathrm{~L} \mathrm{H}_{2} \mathrm{O}$ (final volume)

Autoclave and store up to 1 year at room temperature

Urea loading buffer, $2 \times$

$1.1 \mathrm{~g}$ urea (final concentration $10 \mathrm{M}$ )

$4 \mu \mathrm{L} 2 \%(\mathrm{w} / \mathrm{v})$ xylene cyanol

$980 \mu \mathrm{L}$ distilled $\mathrm{H}_{2} \mathrm{O}$

Dissolve urea at $50^{\circ} \mathrm{C}$

Store in $0.5-\mathrm{mL}$ aliquots up to 1 year at $-20^{\circ} \mathrm{C}$

\section{COMMENTARY}

\section{Background Information}

Native polyacrylamide gel electrophoresis is now well established as a method for characterizing stable nucleic acid-protein complexes (Fried and Crothers, 1981). Complexes that normally dissociate within several minutes were found to be stable during many hours of electrophoresis, apparently due to a "caging" effect of the polyacrylamide matrix (Fried and Crothers, 1981). More recently, this approach has been used to quantify the binding of small RNA substrates to the Tetrahymena ribozyme (Pyle et al., 1990). It has also been used to monitor conformational changes in large and small RNAs (e.g., LeCuyer and Crothers, 1993; Emerick and Woodson, 1994). The mobility of native RNA is correlated with its hydrodynamic radius (Orr et al., 1998), with compact structures migrating more rapidly than extended forms. As a result, this method is most useful when analyzing RNA sequences that fold into defined tertiary structures.

Although these protocols are optimized for analysis of a 657-nt RNA, electrophoretic conditions can be readily varied depending on the RNA to be studied. The author has successfully used gels containing $4 \%$ to $12 \%$ polyacrylamide and 3 to $10 \mathrm{mM} \mathrm{MgCl}_{2}$. Nonionic substrates such as guanosine may be incorporated into the gel matrix. RNA conformers or complexes that exchange on the 1- to 10-min time scale at room temperature can usually be resolved if the appropriate conditions are chosen. This method is not suitable for trapping shortlived intermediates, as 15 to $30 \mathrm{sec}$ are required for samples to enter the polyacrylamide matrix (Pan and Woodson, 1998).
RNA Folding Pathways 
Another advantage of native gel electrophoresis is that it is easily combined with a variety of methods for probing RNA structure, including chemical modification and photo-crosslinking (Branch et al., 1989). Chemical reagents are commonly used to map regions of the RNA that are accessible to the chemical probe (Ehresmann et al., 1987). The modified positions are either detected by treatment of RNA with aniline acetate, which results in strand scission, or by extension of a complementary DNA primer with reverse transcriptase (Inoue and Cech, 1985; Moazed et al., 1986).

A number of organic and inorganic compounds and enzymes that modify nucleic acids have been used to footprint protein-DNA complexes within polyacrylamide gels (Law et al., 1987; Straney and Crothers, 1987), and these methods were extended to the analysis of RNA structure (Emerick and Woodson, 1994). The advantage of modifying RNA in the gel matrix is that the rate of conformational exchange remains low. The disadvantage is that reagents must diffuse through the gel, making it difficult to control reaction time. In addition, some reagents, such as diethylpyrocarbonate, are strongly inhibited by the gel components. An alternative approach that avoids some of these pitfalls is to modify the RNA before electrophoresis, as in modification interference (Pan and Woodson, 1998).

\section{Critical Parameters}

An important parameter that affects separation of different conformational forms of RNA by electrophoresis is whether or not the confor- mational change induces a significant change in the overall shape of the molecule (i.e., by altering tertiary interactions). Beyond this, it is important to ensure that the folded RNA is stable in the electrophoresis and sample buffers, and that the internal temperature of the gel remains below $12^{\circ} \mathrm{C}$. For the Tetrahymena preRNA, the bands representing active and inactive conformers become blurred at $15^{\circ} \mathrm{C}$, and are no longer separated at $20^{\circ} \mathrm{C}$. Two-dimensional electrophoresis and in situ chemical modification require extensive handling of RNA. Even very slight levels of ribonuclease contamination can result in undesirable background at the end of the experiment. To obtain interpretable results, the concentrations of chemical modifying reagents and times of exposure must be adjusted empirically for each RNA sequence, so that each molecule is modified only once on average.

\section{Anticipated Results}

Typical results from native gel electrophoresis of the Tetrahymena pre-RNA are illustrated in Figure 11.4.2. Addition of GTP and RNA substrates to the gel showed that only the more rapidly migrating species was competent to self-splice (Emerick and Woodson, 1994). Consistent with this result, nucleotides in the catalytic core of the intron were more susceptible to modification with DMS and kethoxal in the inactive conformer than in the active form. In general, a qualitative test of ribozyme activity is relatively straightforward, if a reasonable degree of separation in the native gel is obtained. In situ chemical modification of the
Probing RNA Folding Pathways by RNA Fingerprinting

\section{wt mut}

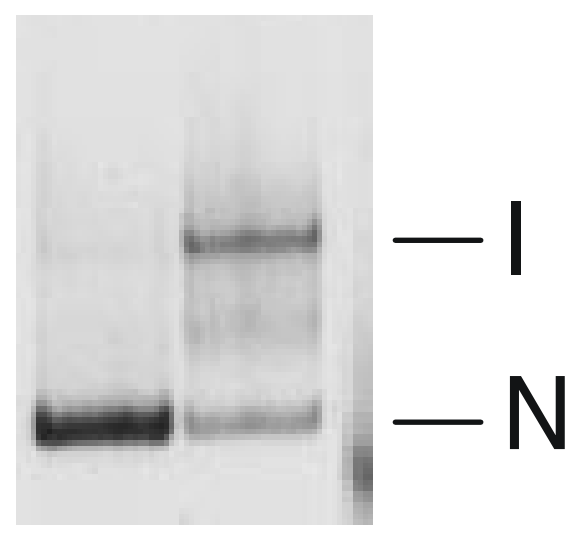

Figure 11.4.2 Native 6\% polyacrylamide gel of ${ }^{32} \mathrm{P}$-labeled Tetrahymena pre-RNA (657-nt). The RNA was annealed at $95^{\circ} \mathrm{C}$ before loading. Abbreviations: I, inactive pre-RNA; N, native (active) RNA; wt, wild type; mut, mutation (170C) that destablizes the active RNA structure. 
RNA is more challenging, and one can expect that several trials will be required before the optimal conditions are found.

\section{Time Considerations}

All of the protocols described here can be carried out in 1 to 3 days. Two-dimensional gel electrophoresis requires a continuous 10- to 12-hr block of time.

\section{Literature Cited}

Branch, A.P., Benedfeld, B.J., Paul, C.P., and Robertson, H.P. 1989. Analysis of ultraviolet-induced RNA-RNA cross-links: A means for probing RNA structure-function relationships. Methods Enzymol. 180:418-442.

Davanloo, P., Rosenberg, A.H., Dunn, J.J., and Studier, F.W. 1984. Cloning and expression of the gene for bacteriophage T7 RNA polymerase. Proc. Natl. Acad. Sci. U.S.A. 81:2035-2039

Ehresmann, C., Baudin, F., Mougel, M., Romby, P., Ebel, J.P., and Ehresmann, B. 1987. Probing the structure of RNAs in solution. Nucl. Acids Res. 15:9109-9128.

Emerick, V.L. and Woodson, S.A. 1993. Self-splicing of the Tetrahymena pre-rRNA is decreased by misfolding during transcription. Biochemistry 32:14062-14067.

Emerick, V.L. and Woodson, S.A. 1994. Fingerprinting the folding of a group I precursor RNA. Proc. Natl. Acad. Sci. U.S.A. 91:9675-9679.

Feinbaum, R. 2000. Introduction to plasmid biology. In Current Protocols in Molecular Biology (F.M. Ausubel, R. Brent, R.E. Kingston, D.D. Moore, J.G. Seidman, J.A. Smith, and K. Struhl, eds.) pp. 1.5.1-1.5.17. John Wiley \& Sons, New York.

Fried, M. and Crothers, D.M. 1981. Equilibria and kinetics of lac repressor-operator interactions by polyacrylamide gel electrophoresis. $\mathrm{Nucl}$. Acids Res. 9:6505-6525.

Inoue, T. and Cech, T.R. 1985. Secondary structure of the circular form of the Tetrahymena rRNA intervening sequence: A technique for RNA structure analysis using chemical probes and reverse transcriptase. Proc. Natl. Acad. Sci. U.S.A. 76:1670-1764.
Law, R., Kuwabara, M.D., Briskin, M., Fasel, N., Hermanson, G., Sigman, D.S., and Wall, R. 1987. Protein-binding site at the immunoglobulin mu membrane polyadenylation signal: Possible role in transcription termination. Proc. Natl. Acad. Sci. U.S.A. 84:9160-9164.

LeCuyer, K.A. and Crothers, D.M. 1993. The Leptomonas collosoma spliced leader RNA can switch between two alternate structural forms. Biochemistry 32:5301-5311.

Milligan, J.F. and Uhlenbeck, O.C. 1980. Synthesis of small RNAs using T7 RNA polymerase. Methods Enzymol. 180:51-62.

Moazed, D., Stern, S., and Noller, H.F. 1986. Rapid chemical probing of conformation in $16 \mathrm{~S}$ ribosomal RNA and 30S ribosomal subunits using primer extension. J. Mol. Biol. 187:399-416.

Orr, J.W., Hagerman, P.J., and Williamson, J.R. 1998. Protein and $\mathrm{Mg}^{2+}$-induced conformational changes in the $\mathrm{S} 15$ binding site of $16 \mathrm{~S}$ ribosomal RNA. J. Mol. Biol. 275:453-464.

Pan, J. and Woodson, S.A. 1998. Folding intermediates of a self-splicing RNA: Mispairing of the catalytic core. J. Mol. Biol. 280:597-609.

Pyle, A.M., McSwiggen, J.A., and Cech, T.R. 1990. Direct measurement of oligonucleotide substrate binding to wild-type and mutant ribozymes from Tetrahymena. Proc. Natl. Acad. Sci. U.S.A. 87:8187-8191.

Straney, D.C. and Crothers, D.M. 1987. Comparison of the open complexes formed by RNA polymerase at the Escherichia coli lac UV5 promoter. J. Mol. Biol. 193:279-292.

Tabor, S. 2000. DNA-dependent RNA polymerases. In Current Protocols in Molecular Biology (F.M. Ausubel, R. Brent, R.E. Kingston, D.D. Moore, J.G. Seidman, J.A. Smith, and K. Struhl, eds.) pp. 3.8.1-3.8.4. John Wiley \& Sons, New York.

Contributed by Sarah A. Woodson Johns Hopkins University

Baltimore, Maryland
RNA Folding Pathways

\subsubsection{7}

